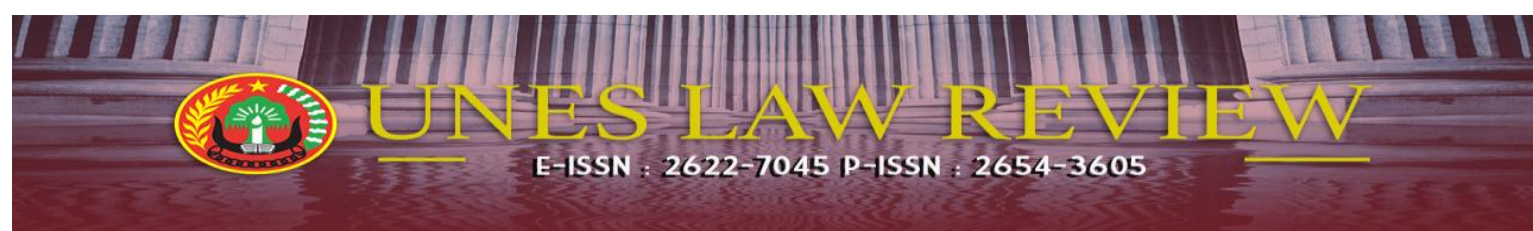

Email : uneslawreview@gmail.com Online : http://review-unes.com/index.php/law/index

Volume 1, Issue 3, Maret, 2019

E-ISSN : 2622-7045

P-ISSN : 2654-3605

\title{
PEMILU YANG BERINTEGRITAS DALAM NEGARA HUKUM DEMOKRATIS
}

\author{
Zennis Helen \\ Program Ilmu Hukum, Universitas Ekasakti \\ Email: zennishelen78@gmail.com
}

\begin{abstract}
The journal entitled Elections with Integrity in the State of Democratic Law was made for several reasons. First, elections are a means of implementing popular sovereignty as the implementation of normative provisions of the 1945 Constitution of the Republic of Indonesia, especially Article 1 Paragraph (2) which states that "Sovereignty be in the hands of the people and carried out according to the Constitution, ". Sovereignty in the hands of the people is also manifested through elections as a means of rotating leadership both at the national and regional levels carried out through direct, general, free and confidential principles. Secondly, elections in the 1945 Constitution are carried out by a general election commission which is referred to by the General Election Commission (KPU), Third, because the means of implementing people's sovereignty carried out by the KPU must be carried out by people who are not only professionals but also must have the main requirements, namely having dignity and integrity, Fourth, so that the implementation of the election is on track in accordance with the provisions of applicable legislation, supervision must be carried out by Law No. 7 of 2017 on Elections called the Election Supervisory Body (Bawaslu)) The General Election Commission (KPU), Bawaslu, as the EMB has hierarchical levels from the central, provincial and district / city levels. This journal has two problem formulations, namely First, What is the urgency of the election as the implementer of popular sovereignty? Second, what is the election with that integrity?
\end{abstract}

Keywords: Pemilu, Integritas, Negara, Hukum, Demokratis.

\section{PENDAHULUAN}

Jurnal yang berjudul tentang Pemilu yang Berintegritas Dalam Negara Hukum Demokratis dibuat karena beberapa alasan, Pertama, pemilu merupakan sarana pelaksanaan kedaulatan rakyat sebagai implementasi ketentuan normatif UndangUndang Dasar Negara Republik Indonesia Tahun 1945, khususnya Pasal 1 Ayat (2) yang menyatakan bahwa " Kedaulatan berada ditangan rakyat dan dilaksanakan menurut Undang-Undang Dasar,”.

Kedaulatan yang berada ditangan rakyat juga dimanifestasikan melalui pemilu sebagai sarana rotasi kepemimpinan baik ditingkat nasional maupun daerah yang dilaksanakan melalui asas langsung, umum, bebas dan rahasia. Kedua, pemilu dalam UUD 1945 
dilaksanakan oleh sebuah komisi pemilihan umum. Oleh UU No 7 Tahun 2017 tentang Pemilihan Umum disebut dengan Komisi Pemilihan Umum (KPU), Ketiga, karena sarana pelaksanaan kedaulatan rakyat yang dilaksanakan oleh KPU haruslah dilaksanakan oleh orang-orang yang tidak hanya profesional melainkan juga harus memeliki persyaratan utama, yakni memeliki martabat dan berintegritas, Keempat, agar pelaksanaan pemilu berada di jalur yang sesuai dengan ketentuan peraturan perundang-undangan yang berlaku maka harus dilakukan pengawasan. UU No 7 Tahun 2017 tentang Pemilu dinamakan dengan Badan Pengawas Pemilu (Bawaslu). Komisi Pemilihan Umum (KPU), Bawaslu sebagai lembaga penyelenggara pemilu mempunyai jenjang yang bersifat hierarki dari tingkat pusat, propinsi hingga kabupaten/kota.

Faktor penyelenggara baik yang berada di Komisi Pemilihan Umum (KPU) maupun di Badan Pengawas Pemilu merupakan faktor penting bagi suksesnya pelaksanaan pemilu. Dalam sebuah kesempatan Taverne pernah mengatakan bahwa " Bukan rumusan undangundang yang menjamin kebaikan pelaksanaan hukum acara pidana tetapi hukum acara pidana yang jelek pun dapat menjadi baik jika pelaksanaan di tangani oleh aparat penegak hukum yang baik. ${ }^{1}$

${ }^{1}$ Yahya Harahap, Pembahasan Permasalahan dan Penerapan KUHAP Penyidikan dan Penuntutan, Sinar Grafika, Jakarta, edisi kedua, 2009, hlm. 6.
Apa yang diucapkan oleh Taverne diatas sangat relevan apabila dikaitkan dalam pelaksanaan pemilu, seperti Pemilihan Kepala Daerah (pilkada) yang telah dilaksanakan pada 27 Juni lalu dan pemilu serentak (baca: pemilu legislatif dan pemilu presiden dan Wakil Presiden) yang akan digelar pada 2019. Bagaimana tidak, sebaik apapun aturan jika dilaksanakan oleh pelaksana dan pengawas yang tidak berintegritas maka sebuah aturan tidak akan dapat ditegakkan. Akan tetapi seburuk apa pun aturan perundang-undangan jika pelaksananya mempunyai integritas dan martabat maka aturan itu akan dapat ditegakkan dengan baik. Lebih konkret lagi adalah pada pelaksanaan pemilu yang tak lama lagi akan dilangsungkan dapat berjalan dengan baik maka diperlukan pelaksana dan pengawas yang berintegritas dan bermartabat. Hal ini mutlak harus ada dan tidak bisa ditawar-tawar lagi. Pemilu yang dilaksanakan secara berintegritas dan bermartabat harus dimulai terlebih dahulu dari penyelenggaranya dan pengawasnya yang kemudian baru diikuti dengan aturan yang dibuat baik undangundang maupun peraturan teknis dengan melibatkan Dewan Perwakilan Rakyat (DPR) sebagai refresentasi kedaulatan rakyat.

\section{HASIL DAN PEMBAHASAN}

\section{Pemilu Pelaksana Kedaulatan Rakyat}

Pemilu merupakan infrastruktur politik ketatanegaraan penting dalam sebuah negara demokrasi. Tidak hanya itu, pemilu sebagai 
sarana pesta demokrasi di Indonesia yang telah dilaksanakan sejak pemilihan umum pertama pada tahun 1955. Pemilihan umum merupakan pilihan bagi bangsa Indonesia dalam menentukan pemimpin bangsa Indonesia dalam menentukan pemimpin bangsa Indonesia secara demokratis sesuai dengan sistem pemerintahan yang dilaksanakan di Indonesia yaitu sistem presidensial dimana kekuasaan eksekutif yang terpisah dengan legislatif dipilih melalui pemilihan umum. ${ }^{2}$

Kedaulatan rakyat atau kerakyatan secara harfiah berarti kekuasaan tertinggi ada pada rakyat. Negara yang menempatkan kekuasaan tertinggi pada rakyat, disebut negara demokrasi yang secara simbolis sering digambarkan sebagai pemerintahan dari rakyat, oleh rakyat, dan untuk rakyat. ${ }^{3}$ Suatu negara dikatakan menjalankan demokrasi apabila memenuhi unsur-unsur yaitu ada kebebasan untuk membentuk dan menjadi anggota perkumpulan, ada kebebasan menyatakan pendapat, ada hak untuk memberikan suara dalam pemungutan suara, ada kesempatan untuk dipilih atau menduduki berbagai jabatan pemerintahan atau negara, ada hak bagi aktivis politik berkampanye untuk memperoleh dukungan atau suara,

2 Encik Muhammad Fauzan, Hukum Tata Negara Indonesia, Setara Press, Malang, 2017, hlm. 158.

3 Bagir Manan, (Editorial), Kedaulatan Rakyat, Hak Asasi Manusia dan Negara Hukum, Kumpulan Esai Guna Menghormati Sri Soemantri Martosoewignjo, Jakarta: Gaya Media Pratama, 1996. terdapat berbagai sumber informasi, ada pemilihan yang bebas dan jujur, semua lembaga yang bertugas merumuskan kebijaksanaan pemerintah, harus tergantung pada keinginan rakyat. ${ }^{4}$

Dengan demikian, salah satu unsurnya adalah hak untuk memberikan suara dalam pemungutan suara maka dapat dikatakan pemilu merupakan salah satu instrumennya. Pemilu dapat menjadi salah satu ukuran untuk menentukan sebuah negara itu demokratis atau tidak, disamping ukuran-ukuran lain yang juga harus dipenuhi. Karena kian pentingnya pemilu itu, ia mendapat pengaturan langsung dalam Pasal 22E ayat (1), ayat (2), ayat (3), ayat (4), ayat (5) Perubahan Ketiga UUD 1945 tahun 2001. Pada ayat (1) “Pemilihan umum dilaksanakan secara langsung, umum, bebas dan rahasia, jujur dan adil setiap lima tahun sekali. Ayat (2) “ pemilihan umum diselenggarakan untuk memilih anggota Dewan Perwakilan Rakyat, Dewan Perwakilan Daerah, Presiden dan Wakil Presiden dan Dewan Perwakilan Rakyat Daerah. Ayat (3) " peserta pemilihan umum untuk memilih anggota Dewan Perwakilan Rakyat, dan Anggota Dewan Perwakilan Rakyat Daerah adalah partai politik, ayat (4) “ peserta pemilihan umum untuk memilih anggota Dewan Perwakilan Daerah adalah

4 Soetardjo Kartohadikusumo, Desa dalam Editor Bagir Manan, Kedaulatan Rakyat, Hak Asasi Manusia dan Negara Hukum, Kumpulan Esai Guna Menghormati Sri Soemantri Martosoewignjo........... hlm. 56 
perseoranga, ayat (5) “ pemilihan umum diselenggarakan oleh suatu komisi pemilihan umum yang bersifat nasional, tetap, dan mandiri. Ayat (6) ketentuan lebih lanjut tentang pemilihan umum diatur dengan undang-undang.

Membaca Pasal 22E ayat (1), ayat (2), ayat (3), ayat (4), ayat (5), ayat (6) UUD Negara Republik Indonesia Tahun 1945 ini mempunyai hubungan yang erat dengan pasal 1 ayat (2) UUD Negara Republik Indonesia Tahun 1945 yang menyatakan bahwa “ Kedaulatan berada ditangan rakyat dan dilaksanakan menurut Undang-Undang Dasar. Dalam sebuah negara demokrasi rakyatlah yang sebenarnya berkuasa dan berdaulat. Manifestasi kedaulatan rakyat itu salah satunya diwujudkan melalui pemilu yang dilaksanakan secara berkala dan dalam sirkulasi yang teratur dan tetap, yakni setiap lima tahun sekali. Bahkan lebih tegas lagi, pemilu merupakan sarana penyaluran hak rakyat dalam bernegara. Kedaulatan yang ada ditangan rakyat dilimpahkan kepada orang yang dipercaya mampu memimpin dan memperjuangkan kepentingan rakyat. ${ }^{5}$ Lebih jauh dari itu, pemilu merupakan proses bagi kemungkinan perguliran kekuasaan yang dilakukan secara damai dan beradab. ${ }^{6}$

Dalam sebuah negara demokrasi rakyat memberikan suara di bilik-bilik suara untuk

${ }^{5}$ M. Afifuddin, Menjaga Hak Pilih Warga, Republika, 28 Juli 2018, hlm. 7

6 M. Alfan Alfian, Hakikat Demokrasi Kontestatif, Kompas, 28 Juli 2018, hlm. 7 memilih pemimpin mereka sekali dalam lima tahun. Suara yang diberikan itu sangat penting dan satu suara pun tidak boleh ada yang terbuang percuma. Negara harus menjamin hak rakyat untuk memberikan suara. Oleh karena itu terjaminnya hak suara rakyat harus menjadi kewajiban jajaran penyelenggara pemilu, terutama dalam proses pemutakhiran data pemilih. ${ }^{7}$ Tidak hanya itu, kedaulatan rakyat disalurkan melalui infrastruktur ketatanegaraan melalui pemilu. Disana tidak hanya pemilu akan tetapi juga ada partai politik, kelompok penekan, kelompok kepentingan, media, figur penting dalam sebuah negara, media masa dan lain-lain sebagainya.

Lebih-lebih, partai politik adalah elemen penting dalam negara demokrasi. Tidak ada negara tanpa partai politik, dan tidak ada partai politik tanpa wakil rakyat. Artinya, antara KPU, Bawaslu, dan DKPP harus bekerjasama dengan baik untuk menyukseskan pemilu. Agar suara rakyat tersalurkan dengan baik maka diperlukan penyelengara pemilu KPU, Bawaslu dan DKPP. Ketiganya merupakan organ penting dalam penyelenggaraan pemilu. Ujung tombak suksesnya sebuah pesta demokrasi terletak pada kerjasama yang baik antara peserta pemilu (baca: partai politik) dan penyelenggara pemilu.

\footnotetext{
${ }^{7}$ M. Afifuddin, Menjaga Hak......, Ibid
} 
Oleh karena kian pentingnya fungsi organ penyelenggara pemilu maka penyelenggara pemilu memeliki tanggung jawab moral dalam menjamin terlaksananya penyaluran kedaulatan rakyat. Tidak satupun rakyat yang memeliki hak pilih, hilang akibat hal teknis, seperti perekaman KTP-el yang tidak dilakukan. ${ }^{8}$ Dalam konteks lain juga dalam sebuah negara demokrasi yang berkedaulatan rakyat itu rakyat memilih secara langsung pemimpin mereka. Misalnya dalam pemilu serentak yang akan dilangsungkan pada 27 April 2019 mendatang, rakyat secara langsung memilih calon anggota legislatif dan Presiden dan/atau wakil Presiden. Demokrasi langsung tidak mungkin diterapkan karena wilayah Indonesia sangat luas, penduduknya tidak sedikit, kepentingan beragam. Oleh karena itu yang lebih cocok adalah demokrasi perwakilan. Rakyat memilih wakil mereka di parlemen. Kedaulatan itu diserahkan kepada orang yang mereka percaya melalui instrumen demokrasi melalui pemilu.

Demokrasi langsung dapat diterapkan pada negara yang kecil, yang jumlah penduduknya sedikit, dan juga luas wilayah yang tidak begitu besar. Untuk konteks Indonesia dengan jumlah penduduk yang sangat banyak, wilayah teriotorial yang sangat luas maka lebih cocok adalah demokrasi tidak langsung. Tapi jangan lupa bahwa penentuan siapa yang melaksanakan kedaulatan rakyat itu ditentukan melalui pemilu yang dilaksanakan secara reguler satu kali lima tahun. Saat ini DPR dan pemerintah mengupayakan pemilu itu dilaksanakan secara serentak. Hal itu mulai dari Pilkada yang dilaksanakan secara serentak gelombang pertama pada tahun 2015, gelombang kedua pada tahun 2017 dan gelombang ketiga pada tahun 2018 lalu, pemilu serentak pada 2019.

Pemilu pun harus dilaksanakan sesuai dengan hukum. Oleh karena itu untuk pelaksanaan pemilu 2019 telah diatur dengan UU No 7 Tahun 2017 tentang Pemilihan Umum. Kenapa harus didasarkan pada hukum? Karena pasal 1 ayat (3) UUD Negara Republik Indonesia Tahun 1945 yang mengatakan bahwa“ Negara Indonesia adalah negara hukum. Bukan berdasarkan atas kekuasaan. Menyigi tentang negara hukum tidak dapat lepas dari cita hukum (rechtsidee) Pancasila sebagai pedoman. Menurut A. Hamid S Attamimi, kelima sila dari Pancasila dalam kedudukannya sebagai cita hukum rakyat Indonesia dalam kehidupan bermasyarakat, berbangsa dan bernegara secara posisi merupakan bintang pemandu yang memberikan pedoman dan bimbingan dalam semua kegiatan, serta memberi isi kepada tiap peraturan perundang-undangan. Secara negatif merupakan rangka yang

\section{${ }^{8}$ Ibid}


membatasi ruang gerak isi peraturan perundang-undangan tersebut. ${ }^{9}$

Lebih lanjut dikatakan, sila-sila Pancasila, harusnya menjadi pedoman dalam penyusunan peraturan perundang-undangan, serta menjadi arah bagi politik hukum Indonesia secara keseluruhan. Pancasila sebagai asas dan cita hukum, menjadi pedoman dan bintang pemandu (leitstern) bagi UUD 1945, bagi undang-undang dan bagi peraturan perundang-undangan lainnya. ${ }^{10} \mathrm{Jika}$ dikaitkan antara kedaulatan rakyat yang penulis katakan tadi yang salah salah satunya diwujudkan melalui infrastruktur ketatanegaraan melalui pemilu maka harus menjadikan Pancasila sebagai bintang pemandu yang tidak saja dalam pembentukan UU No 7 Tahun 2017 Tentang Pemilu akan tetapi juga dalam setiap pembentukan peraturan Komisi Pemilihan Umum (PKPU), Peraturan Badan Pengawas Pemilu (Perbawaslu) dan Peraturan yang dikeluarkan oleh Dewan Kehormatan Penyelenggra Pemilu (DKPP). Pelaksanaan kedaulatan rakyat itu harus diikat oleh aturan hukum.

Jika tidak maka penyelenggara pemilu dapat dikatakan lalim dan sewenang-wenang.

9 A. Hamid S. Attamimi, Pancasila Cita Hukum dalam Kehidupan Hukum Bangsa Indnesia, Pancasila sebagai ideologi dalam berbagai bidang kehidupan bermasyarakat, berbangsa dan bernegara dalam Otong Rosadi, Pertambangan dan Kehutanan Dalam Perspektif Cita Hukum Pancasila Dialektika Hukum dan Keadilan Sosial, Penerbit Thafa Media, cet 1, 2012, hlm. 2.

${ }^{10}$ Zainuddin Amali, Filsafat Hukum dalam Otong Rosadi, Pertambangan dan Kehutanan........... Ibid
Dalam konsideran menimbang UU No 7 Tahun 2017 tentang Pemilu pun disebutkan bahwa diperlukan pengaturan pemilihan umum sebagai perwujudan sistem ketatanegaraan yang demokratis dan berintegritas demi menjamin konsistensi dan kepastian hukum serta pemilihan umum yang efektif dan efisien. Bahkan Bernard L Tanya mengatakan bahwa hukum sebagai alat untuk mencapai tujuan negara selain berpijak pada lima dasar untuk mencapai tujuan negara, juga harus berfungsi dan berpijak pada empat prinsip cita hukum (rechtsidee), yakni melindungi semua unsur bangsa (nation), demi keutuhan (integrasi), mewujudkan keadilan sosial dalam bidang ekonomi dan kemasyarakatan mewujdjab kedaulatan rakyat (demokrasi) dan negara hukum (nomokrasi), menciptakan toleransi atas dasar kemanusiaan dan berkeadilan dalam hidup beragama. ${ }^{11}$

Dalam konteks negara hukum tidak bisa lepas dari jenis dan hierarki peraturan perundang-undangan sebagaimana yang diatur oleh Pasal 7 ayat (1) UU No 12 Tahun 2011 Tentang Pembentukan Peraturan PerundangUndangan, yakni a) Undang-Undang Dasar Negara Republik Indonesia Tahun 1945, b) Ketetapan Majelis Permusyawaratan Rakyat, c) Undang-Undang/Peraturan Pemerintah Pengganti Undang-Undang (Perppu), d) Peraturan Pemerintah, e) Peraturan Presiden,

11 Bernard L Tanya dalam Moh Mahfud MD, Membangun Politik Hukum, Menegakkan Konstitusi dalam Otong Rosadi, Pertambangan dan Kehutanan...........,hlm. 3 
f) Peraturan Daerah Propinsi, g) Peraturan Daerah Kabupaten/Kota. Membaca Pasal 7 ayat (1) diatas terasa tidak lengkap jika tidak dibaca Pasal 8 ayat (1) UU aquo yang menyatakan bahwa “ jenis peraturan perundang-undangan selain sebagaimana dimaksud pada pasal 7 ayat (1) mencakup peraturan yang ditetapkan oleh Majelis Permusyawaratan Rakyat, Dewan Perwakilan Rakyat, Dewan Perwakilan Daerah, Mahkamah Agung, Mahkamah Konstitusi, Badan Pemeriksa Keuangan, Komisi Yudisial, Bank Indonesia, Menteri, Badan, dan Lembaga atau komisi yang setingkat yang dibentuk dengan undang-undang atau pemerintah atas peruntah undang-undang, Dewan Perwakilan Rakyat Daerah Propinsi, Gubernur, Dewan Perwakilan Rakyat Daerah Kabupaten/kota, Bupati/Walikota, kepala desa atau yang setingkat.

Pasal ini menyebutkan bahwa lembaga atau komisi yang setingkat. Penulis berpandangan komisi yang setingkat itu salah satunya adalah Komisi Pemilihan Umum (KPU) yang merupakan penyelenggara pemilu yang tidak saja disebut dalam UUD 1945 akan tetapi juga disebut dan diatur dalam undangundang. Undang-Undang No 7 Tahun 2017 menyebutnya dengan Komisi Pemilihan Umum (KPU). Dalam konteks penyelenggaraan pemilu tidak saja diatur dalam UU No 7 Tahun 2017 dan agar undangundang ini dapat dioperasionalkan maka diperlukan peraturan komisi pemilihan umum
(PKPU) yang kedudukannya sederajat dengan Peraturan pemerintah dalam jenis dan hierarki peraturan perundang-undangan. Kelebihannya dengan peraturan Pemerintah adalah peraturan pemerintah adalah kewenangan pemerintah dalam rangka melaksanakan undang-undang akan tetapi peraturan komisi pemilihan umum harus dikonsultasikan dengan Dewan Perwakilan Rakyat (DPR) yang bersifat mengikat.

Penulis berpandangan bahwa kedaulatan yang diserahkan oleh rakyat kepada penyelenggara pemilu itu agar produknya dapat dipercaya maka ia harus dibatasi dan dibungkus dengan aturan hukum. Hal ini disebabkan karena Indonesia sudah mengikrarkan dirinya sebagai negara hukum. Maka dalam konteks negara hukum tidak boleh tidak semua kebijakan dan keputusan yang dikeluarkan oleh negara harus berdasarkan pada hukum. Ketika KPU menterjemahkan UU No 7 Tahun 2017 tentang Pemilu ke dalam Peraturan Komisi Pemilihan Umum (PKPU) harus selaras dan sesuai dengan UU Pemilu karena ia terikat pada asas dalam perundang-undangan yaitu lex superior derogate legi inferiori (peraturan perundang-undangan yang lebih rendah tidak boleh bertentangan dengan peraturan perundang-undangan yang lebih tinggi). Jika bertentangan maka tersedia perangkat hokum untuk mengujinya baik secara litigasi maupun non litigasi. Secara litigasi melalui pengujian PKPU itu ke Mahkamah Agung (MA). 
Misalnya PKPU No 20 Tahun 2018 tentang pencalonan Anggota DPR dan DPRD yang mengatur tentang larangan narapidana Narkoba, Kejahatan Seksual terhadap anak, dan tindak pidana korupsi yang pada akhirnya dibatalkan oleh Mahkamah Agung (MA).

Satu hal yang tidak boleh dilupakan bahwa dalam konteks negara hukum ini dikenal adanya pengujian undang-undang. Semua peraturan perundang-undangan dapat diuji. Ketika UU bertentangan dengan UUD 1945 diuji di Mahkamah Konstitusi dan peraturan perundang-undangan yang berada dibawah undang-undang terhadap undangundang diuji di Mahkamah Agung (MA) dan keputusan tata usaha negara yang bersifat keputusan/penetapan diuji di peradilan tata usaha negara serta keputusan pengadilan tingkat pertama diuji di tingkat banding dan putusan hakim tingkat banding dapat diuji di tingkat kasasi dan sebagainya.

Namun ada perkembangan terbaru dalam hal pengujian undang-undang yang tidak hanya melalui pengadilan akan tetapi juga dapat melalui jalur diluar pengadilan (non litigasi). Hal itu telah diatur dengan Peraturan Menteri Hukum dan Hak Asasi Manusia Republik Indonesia No 32 Tahun 2017 tentang Tata Cara Penyelesaian Sengketa Peraturan Perundang-undangan Melalui Jalur Nonlitigasi. Regulasi ini bertujuan untuk menyelesaikan sengketa peraturan perundang-undangan baik secara vertikal maupun horizontal yang menyebabkan konflik norma hukum.

Bahkan, kekuasaan harus dalam praktik pengunaannya harus dapat diuji dan pembatasannya harus dilakukan dengan menggunakan perangkat hukum. Pendek kata, kekuasaan itu harus dibatasi. Pernyataan yang disampaikan oleh Lord Acton sangat relevan hingga saat ini, ia mengatakan power tend to corrupt absolut power to corrupt absolutely (kekuasaan cenderung korup dan kekuasaan yang korup pasti akan korup). Termasuk dalam hal ini Komisi Pemilihan Umum (KPU) dan Badan Pengawas Pemilu (Bawaslu) serta Dewan Kehormatan Penyelenggara Pemilu (DKPP). Sebagai lembaga negara kekuasaan dibatasi oleh hukum. Pembatasan kekuasaan itu menyangkut dua hal, a) pembatasan kekuasaan yang meliputi isi kekuasaannya, b) pembatasan kekuasaan yang berkenaan dengan waktu dijalankan kekuasaan tersebut. ${ }^{12}$ Sekali lagi, bahwa penyelengara negara termasuk komisi pemilihan umum, badan pengawas pemilu dan dewan kehormatan penyelengara pemilu harus dibatasi oleh hukum. Jika tidak berdasarkan hukum maka akan rentan digugat oleh warga negara melalui mekanisme pengujian peraturan perundang-undangan dibawah undang-undang (baca; peraturan komisi pemilihan umum (PKPU) yang oleh UU No

${ }^{12}$ Padmo Wahjono, Masalah Ketatanegaraan Indonesia Dewasa Ini, dalam Dahlan Thaib, Jazim Hamidi, Ni,matul Huda, Teori dan Hukum Konstitusi, Jakarta: Rajawali Pers, 2012, hlm. 22. 
12 Tahun 2011 dilakukan melalui Mahkamah Agung (MA).

\section{Pemilu yang Berintegritas}

Pencantuman kata integritas dalam jurnal ini dilatarbelakangi oleh sebuah ungkapan yang diutarakan oleh Taverne yang mengatakan bahwa " Bukan rumusan undangundang yang menjamin kebaikan pelaksanaan hukum acara pidana tetapi hukum acara pidana yang jelek pun dapat menjadi baik jika pelaksanaan di tangani oleh aparat penegak hukum yang baik. Apa yang diucapkan oleh Taverne diatas sangat relevan apabila dikaitkan dengan pelaksanaan pemilu serentak (baca: pemilu legislatif dan pemilu presiden dan Wakil Presiden) yang akan digelar pada 2019 mendatang.

Bagaimana tidak, sebaik apapun aturan jika dilaksanakan oleh pelaksana dan pengawas yang tidak berintegritas maka sebuah aturan tidak akan dapat ditegakkan. Akan tetapi seburuk apa pun aturan perundang-undangan jika pelaksananya mempunyai integritas dan martabat maka aturan itu akan dapat ditegakkan dengan baik. Lebih konkrit lagi adalah pada pelaksanaan pemilu yang tak lama lagi akan dilangsungkan dapat berjalan dengan baik maka diperlukan pelaksana dan pengawas yang berintegritas. Terkait dengan integritas ini seringkali arti dari kesuksesan selalu dinilai dari berapa banyak uang atau kekayaan yang dimiliki seseorang.
Padahal sesungguhnya kesuksesan tanpa integritas adalah sebuah kegagalan. ${ }^{13}$ Padahal, integritas sendiri memiliki arti yakni suatu sikap hati untuk terus mengambil keputusan dan bertindak dari pemahaman pada prinsip kebenaran yang hakiki apapun resikonya. Dan sikap seperti inilah yang berkenan di mata Sang Pencipta.

Dalam kamus Bahasa Indonesia orang yang berintegritas adalah seseorang yang memiliki kekonsistenan dan keteguhan hati yang tak tergoyahkan dalam menjunjung tinggi nilai-nilai luhur dan keyakinan. Di dalam etika sendiri, integritas diartikan sebagai kejujuran dan kebenaran dari tindakan seseorang. Setidaknya ada 8 hal yang harus diketahui mengenai integritas hidup seperti yang dijelaskan oleh Steven Agustinus seorang Potential Explorer dan Motivator yang handal adalah : a) itegritas selalu berkaitan dengan nama baik, b) integritas membutuhkan pengorbanan, c) integritas terbangun sejalan dengan pengambilan keputusan dalam hidup, d) integritas membuat seseorang tahan uji, e) integritas memberikan kemampuan untuk memimpin, f) integritas berkaitan dengan sikap hati yang berkenan di hadapan sang pencipta, g) orang yang tidak memeliki integritas akan banyak menerima penolakan, h) butuh waktu lama untuk

\footnotetext{
http://indonesiaone.org/8-hal-pentingtentang-integritas-yang-harus-kamu-ketahui/ diakses tanggal 29 Juli 2018 pukul 13.00 WIB.
} 
memulihkan integritas. ${ }^{14}$ Masalah integritas menjadi perbincangan publik akhir-akhir ini. Misalnya dalam konteks penyelenggaraan pemilu sering terdengar kata-kata pemilu yang berintegritas. Bahkan saking pentingnya Komisi Pemilihan Umum membuat fakta integritas yang ditujukan kepada partai politik agar menyuguhkan kader-kader beritegritas untuk dicalonkan dalam pemilu legislatif 2019 mendatang, atau dalam rekrutmen pejabatpejabat di lembaga negara tidak luput dari kata-kata integritas. Tidak hanya itu, pasca reformasi 1998 seringkali fakta integritas dijadikan prasyarat untuk membuktikan komitmen atas integritas calon pejabat publik. $^{15}$

\section{PENUTUP}

Pemilu merupakan pelaksana kedaulatan rakyat karena tanpa pemilu tidak ada ruang bagi rakyat untuk berpartisipasi dalam pemerintahan dan pemilu juga sebaga salah satu unsur negara demokrasi. Pemilu itu harus dilaksanakan secara berintegritas yang dimulai dari penyelengaranya (baik KPU, Bawaslu dan DKPP), dan disamping itu juga ditopang oleh aturannya yang sesuai dengan peraturan perundang-undangan yang lebih tinggi.

\footnotetext{
14 http://indonesiaone.org/8-hal-pentingtentang-integritas-yang-harus-kamu-ketahui/ diakses tanggal 29 Juli 2018 pukul 13.00 WIB.

15 Rio Christiawan, Politik Cerdas Berintegritas, Republika, 28 Juli 2018, hlm. 7.
}

\section{DAFTAR PUSTAKA}

Dahlan Thaib, Jazim Hamidi, Ni,matul Huda, Teori dan Hukum Konstitusi, Jakarta: Rajawali Pers, 2012.

Editor Bagir Manan Kedaulatan Rakyat, Hak Asasi Manusia dan Negara Hukum, Kumpulan Esai Guna Menghormati Sri Soemantri Martosoewignjo, Jakarta: Gaya Media Pratama, 1996

Encik Muhammad Fauzan, Hukum Tata Negara Indonesia, Setara Press, Malang

Otong Rosadi, Pertambangan dan Kehutanan Dalam Perspektif Cita Hukum Pancasila Dialektika Hukum dan Keadilan Sosial, Penerbit Thafa Media, cet 1, 2012.

Yahya Harahap, Pembahasan Permasalahan dan Penerapan KUHAP Penyidikan dan Penuntutan, Sinar Grafika, Jakarta, edisi kedua, 2009 